\title{
HARMONISASI REGULASI KEPEMILIKAN TANAH PERTANIAN SECARA ABSENTEE BAGI PEGAWAI NEGERI DALAM PROGRAM LANDREFORM
}

\author{
Yunizar Wahyu Tristanto \\ PERADI Rumah Bersama Advokat \\ Jl. Mayjend Panjaitan No 4 Malang \\ E-mail : yunizar032@gmail.com
}

\begin{abstract}
Peoples needs can not be separated from the need of land. Once the importance of soil functions for society, need to be regulated in order to ensure the mastery and utilization at the same time in order to create legal certainty for the public. The problem that then arises since the start time of independence is disproportionate land ownership. In order to overcome these problems, the government has enacted Law No. 5 of 1960 About the Agrarian and the Reformation has been set TAP MPR No. IX / MPR / 2001 on Agrarian Reform and Natural Resources Management. One important aspect of the law with the enactment of the UUPA is a program of Landreform in Indonesia . Landreform became one of the alternatives for agrarian justice to resolve agrarian disputes and conflicts. one of the land reform program is the prohibition of absentee ownership of agricultural land. The problem that then occurs is the existence of exceptions in absentee land ownership. The problems regarding the permissibility of absentee ownership of agricultural land by the Servants. The exception contained in Article 3 Paragraph (4) of Government Regulation No. 224 of 1961 on the implementation of Land Distribution and Provision of Compensation. Ownership and control of agricultural soils in absentee in Article 10 Paragraph (1) UUPA is basically prohibited, but in Article 3 Paragraph (4) PP No. 224 years 1961, the government granted an exemption absentee ownership of agricultural land to some legal subjects of the Servant, retired civil servants, widows and widows of civil servants retired civil servants.
\end{abstract}

Keywords: Conflict, Farmland Setting, Landreform, Absentee, Civil Servants

\begin{abstract}
Abstrak
Kebutuhan hidup masyarakat tidak dapat terlepas dari kebutuhan akan tanah. Begitu pentingnya fungsi tanah bagi masyarakat, perlu diatur agar terjamin dalam penguasaan dan pemanfaatannya sekaligus agar terciptanya kepastian hukum bagi masyarakat. Permasalahan yang kemudian muncul sejak mulai masa kemerdekaan adalah kepemilikan tanah yang tidak proporsional. Dalam rangka mengatasi masalah tersebut, pemerintah telah mengesahkan Undang-Undang Nomor 5 Tahun 1960 Tentang Pokok-Pokok Agraria dan pada masa Reformasi telah di tetapkan TAP MPR Nomor IX/MPR/2001 tentang Pembaruan Agraria dan Pengelolaan Sumber Daya Alam. Salah satu aspek hukum penting dengan diundangkannya UUPA tersebut adalah program Landreform di Indonesia. Landreform menjadi salah satu alternatif untuk mewujudkan keadilan agraria yang dapat menyelesaikan sengketa dan konflik agraria. salah satu program dari Landreform adalah larangan pemilikan tanah pertanian secara absentee. Permasalahan yang kemudian terjadi adalah adanya pengecualian-pengecualian
\end{abstract}


dalam pemilikan tanah absentee. Permasalahan tersebut mengenai diperbolehkannya pemilikan tanah pertanian secara absentee oleh Pegawai Negeri. Pengecualian tersebut terdapat pada Pasal 3 Ayat (4) Peraturan Pemerintah Nomor 224 Tahun 1961 Tentang Pelaksanaan Pembagian Tanah dan Pemberian Ganti Kerugian. Pemilikan dan penguasaan tanah pertanian secara absentee dalam Pasal 10 Ayat (1) UUPA pada dasarnya dilarang, namun dalam Pasal 3 Ayat (4) PP No. 224 tahun 1961 pemerintah memberikan pengecualian pemilikan tanah pertanian secara absentee kepada beberapa subjek hukum yakni Pegawai Negeri, pensiunan pegawai negeri, janda pegawai negeri dan janda pensiunan pegawai negeri.

Kata Kunci: Konflik, Pengaturan Tanah Pertanian, Landreform, Absentee, Pegawai Negeri

\section{A. PENDAHULUAN}

Indonesia adalah negara hukum, ${ }^{1}$ sebagaimana tercantum jelas dalam Pasal 1 Ayat 3 Undang-Undang Dasar Negara Republik Indonesia Tahun 1945 (selanjutnya disebut UUDN RI 1945) hal ini menjelaskan bahwa Indonesia merupakan negara yang menganut teori kedaulatan hukum (Rechts-souvereiniteit), ${ }^{2}$ tidak berdasar atas kekuasaan belaka (Machtsstaat) dan Pemerintahannya berdasar atas sistem konstitusi (hukum dasar), tidak bersifat absolutisme /kekuasaan yang tidak terbatas.

Negara mempunyai tujuan untuk mensejahterakan setiap rakyatnya, Indonesia mencantumkan tujuan negara tersebut dalam alenia keempat Pembukaan UUDN RI 1945 yakni “...melindungi segenap bangsa Indonesia dan seluruh tumpah darah Indonesia dan untuk memajukan kesejahteraan umum...” yang kemudian dijabarkan pada Pasal 33 Ayat 3 yakni "Bumi dan air dan kekayaan alam yang terkandung di dalamnya dikuasai oleh negara dan dipergunakan untuk sebesar-besar kemakmuran rakyat".

Bahwasannya negara wajib untuk menyediakan kebutuhan dasar masyarakatnya dengan memanfaatkan kekayaan yang terkandung di bumi Indonesia. Oleh karena itu, negara diberikan sebuah wewenang untuk mengatur dan mengurus sumber daya yang ada di seluruh wilayah Indonesia dalam rangka memajukan kemakmuran masyarakat tersebut. ${ }^{3}$

Konsep negara kesejahteraan ini mendorong negara agar tidak hanya berperan sebagai pengatur (reguleren), seperti dalam konsep negara penjaga malam. Namun, negara juga dituntut untuk mengurus dan memajukan kesejahteraan umum (bestuurzoorg) masyarakatnya.

\footnotetext{
${ }^{1}$ Isrok dan Dhia Al Uyun, Ilmu Negara (Berjalan dalam Dunia Abstrak), UB Press, Malang: 2010, hlm 34.

2 Krabbe mengemukakan mengenai teori kedaulatan hukum (Rechts-souvereiniteit) yakni yang memiliki kekuasaan tertinggi didalam suatu negara adalah hukum itu sendiri. Karena baik penguasa, rakyat bahkan negara itu sendiri semuanya tunduk dan patuh kepada hukum. Segala sikap, tingkah laku bahkan kebijakan yang di ambil harus sesuai dengan hukum. Lihat, Soehino, Ilmu Negara, edisi ke-3 cetakan pertama, Liberty, Yogyakarta: 1998, hlm 156.

${ }^{3}$ I Gede Pantja Astawa dan Inna Junaenah, Indeks Otonomi Daerah: Tawaran Titik Temu Negara Hukum dan Pembangunan di Aras Lokal, dalam Susi Dwi Harijati (Ed), Negara Hukum yang berkeadilan, kumpulan pemikiran dalam rangka purnabakti Prof. Dr. Bagir Manan, S.H., M.Cl., PSKN FH UNPAD, Bandung, 2011, hlm 538-539.
} 
Perluasan tugas negara tersebut ditujukan seluas-luasnya untuk menciptakan dan memenuhi kebutuhan dasar bagi tiap-tiap warga negara.

Kebutuhan hidup masyarakat tidak dapat terlepas dari kebutuhan masyarakat akan tanah. setiap orang tumbuh dan berkembang di atas tanah, petani bekerja mengandalkan tanah sebagai lahan pertanian, setiap orang bertempat tinggal dan mendirikan tempat tinggalnya di atas tanah. Begitu pentingnya fungsi tanah bagi masyarakat, perlu diatur agar terjamin dalam penguasaan dan pemanfaatannya sekaligus agar terciptanya kepastian hukum bagi masyarakat.

Permasalahan yang ada di Indonesia sejak masa kemerdekaan adalah kepemilikan tanah yang tidak proporsional, serta kebutuhan akan tanah pertanian yang semakin meningkat sementara jumlah penduduk semakin bertambah pesat. Dalam rangka mengatasi masalah tersebut, pemerintahan Presiden Sukarno telah mengesahkan Undang-Undang Nomor 5 Tahun 1960 Tentang Pokok-Pokok Agraria (selanjutnya disebut UUPA) dan pada masa Reformasi telah di tetapkan TAP MPR Nomor IX/MPR/2001 tentang Pembaruan Agraria dan Pengelolaan Sumber Daya Alam (selanjutnya disebut TAP MPR).

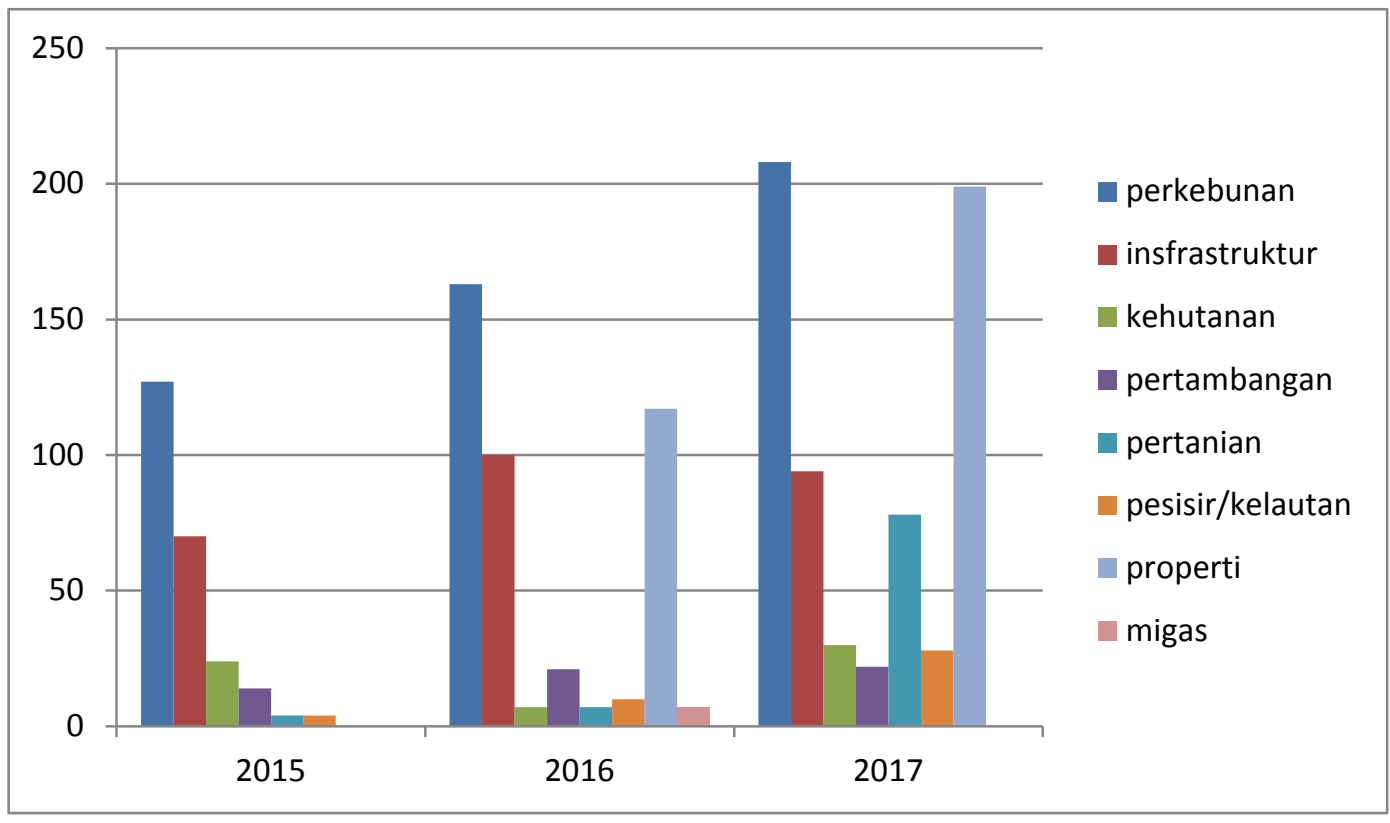

Tabel 1 Jumlah Konflik Agraria per Sektor 2015-2017

Dalam tabel diatas ${ }^{4}$ yang dirilis oleh Konsorsium Pembaruan Agraria (KPA), ada beberapa konflik yang meningkat, tiga tertinggi dalam peningkatan konflik ada di sektor perkebunan yang meningkat dari 127 konflik pada tahun 2015 meningkat menjadi 163 konflik pada tahun 2016 dan meningkat menjadi 208 konflik pada tahun 2017. Selanjutnya peningkatan konflik terlihat pada sektor properti, pada tahun 2016 terjadi 117 konflik dan 199 konflik terjadi pada tahun 2017. Kemudian pada sektor pertanian pada tahun 2015 terjadi 4

\footnotetext{
${ }^{4}$ Catatan Akhir Tahun 2015-2017 Konsosrsium Pembaruan Agraria (KPA), Jakarta
} 
konflik menigkat menjadi 7 konflik pada tahun 2016 dan meningkat menjadi 78 konflik pada tahun 2017.

Konflik agraria hingga saat ini masih terus terjadi bahkan semakin marak dan semakin merata di seluruh wilayah Indonesia. Eskalasi konflik agraria memerlukan dengan segera penyelesaian sengketa secara menyeluruh, sistematis, berkepastian hukum dan adil. Permasalahan tanah sekarang sudah merambah kepada persoalan sosial yang kompleks dan memerlukan pemecahan dengan pendekatan secara komprehensif ${ }^{5}$

Salah satu aspek hukum penting dengan diundangkannya UUPA tersebut adalah dicanangkannya program Landreform di Indonesia. Program tersebut diantaranya: ${ }^{6}$

Pembatasan luas maksimal penguasaan tanah; Larangan pemilikan tanah secara absentee (guntai); Redistribusi tanah-tanah yang menjadi kelebihan dari batas maksimal, tanah-tanah yang terkena larangan absentee, tanah-tanah bekas swapraja dan tanah-tanah negara; Pengaturan berkaitan dengan pengembalian dan penebusan tanah-tanah pertaniannyang digadaikan; pengaturan kembali perjanjian bagi hasil tanah pertanian; Penetapan luas minimum pemilikan tanah pertanian disertai larangan untuk melakukan perbuatan-perbuatan yang mengakibatkan pemecahan pemilikan tanah-tanah pertanian menjadi bagianbagian yang terlampau kecil.

Pada dasarnya, Landreform merupakan suatu upaya perubahan struktural yang mendasarkan diri pada hubungan-hubungan intra dan antar subyek-subyek agraria dalam kaitan akses (penguasaan dan pemanfaatan) terhadap obyek-obyek agraria. Namun secara konkret, pembaruan agraria diarahkan untuk melakukan perubahan struktur penguasaan tanah dan perubahan jaminan kepastian penguasaan tanah bagi rakyat yang memanfaatkan tanah dan kekayaan alam yang menyertainya ${ }^{7}$.

Namun dalam tatanan perundang-undangan terjadi sebuah konflik hukum yakni antara Pasal 10 Ayat (1) UUPA dengan Pasal 3 Ayat (4) PP No. 224 tahun 1961. Ketidak-sinkronan tersebut adalah Pasal 10 Ayat (1) UUPA menyebutkan bahwa "setiap orang dan badan hukum harus mengerjakan sendiri tanahnya secara aktif" namun dalam Pasal 3 Ayat (4) PP No. 224 tahun 1961 pemerintah memberikan pengecualian pemilikan tanah pertanian secara absentee kepada beberapa subjek hukum yakni Pegawai Negeri, pensiunan pegawai negeri, janda pegawai negeri dan janda pensiunan pegawai negeri.

\section{B. RUMUSAN PERMASALAHAN}

Melihat dari uraian data diatas, penulis tertarik untuk membahasa tentang upaya harmonisasi regulasi kepemilikan tanah pertanian secara absentee bagi pegawai negeri dalam program landreform untuk mewujudkan reforma agraria secara menyeluruh dari peraturan perundang-undangan yang ada supaya semangat reforma agraria dapat dijalankan sepenuhnya.

\footnotetext{
${ }^{5}$ Benhard Limbong, Politik Pertanahan, Margaretha Pustaka, Jakarta: 2014, hlm 63.

${ }^{6}$ Supriadi, Hukum Agraria, Sinar Grafika, Jakarta: 2007, hlm 203.

${ }^{7}$ Ida Nurlinda, Prinsip-prinsip Pembaruan Agraria: Perspektif Hukum, Rajawali Pers, Jakarta: 2009, hlm. 77.
} 


\section{METODE PENELITIAN}

Jurnal ini menggunakan jenis penelitian Hukum Yuridis Normatif dengan menggunakan metode pendekatan sebagai berikut: Penelitian ini menggunakan penelitian hukum dengan pendekatan peraturan perundang-undangan (statute approach) yaitu pendekatan dengan menggunakan menelaah dan menganalisis peraturan perundangan-undangan ${ }^{8}$ yang berkaitan dengan tanah pertanian. Analisis terhadap peraturan perundang-undangan tersebut kemudian dibahas guna memahami permasalahan serta solusi yang tepat berdasarkan kebijakan hukum dan asas dalam peraturan perundang-undangan tersebut.

Kemudian peneliti juga menggunakan pendekatan konsep (conseptual approach) yaitu pendekatan dengan menelaah konsep-konsep ${ }^{9}$ yang berhubungan dengan pengecualianpengecualian yang ada dalam peraturan-peraturan tentang pertanahan yang masih berlaku.

\section{HASIL DAN PEMBAHASAN}

\section{Pengaturan Larangan Pemilikan Tanah Pertanian Secara Absentee Menurut UUPA}

Indonesia setelah kemerdekaan mengalami salah satu permasalahan mendasar di bidang hukum pertanahan, yaitu terdapat masalah kepemilikan tanah yang tidak proporsional karena kebutuhan tanah pertanian yang meningkat dan pertumbuhan penduduk yang semakin pesat, sehingga antara ketersediaan tanah dan kebutuhan tanah tidak seimbang.

Tanah sering dilihat sebagai sumber daya alam yang harus dipertahankan untuk generasi mendatang sehingga tidak mengherankan jika terjadi konflik untuk memperebutkan sumber daya ini. Tanah tidak hanya sekadar aset, tetapi juga merupakan basis bagi peralihan kuasa-kuasa ekonomi, sosial, dan politik. ${ }^{10}$

Pemerintah saat itu melakukan berbagai upaya salah satunya adalah menyusun ketentuan hukum keagrariaan dengan ditandai dibentuknya berbagai kepanitiaan dengan maksud untuk merombak ketentuan yang diatur dalam Agrarische Wet (1870). Mulai dari Panitia Agraria Yogya (1948), Panitia Agraria Jakarta (1951), Panitia Suwahyo (1956), Rancangan Sunaryo (1958) dan Rancangan Sadjarwo (1960). ${ }^{11}$

Pada tanggal 24 September 1960 bangsa Indonesia akhirnya memiliki UndangUndang Nomor 5 Tahun 1960 Tentang Peraturan Dasar Pokok-Pokok Agraria atau yang lebih dikenal dengan nama UUPA yang mulai berlaku pada tanggal 24 September 1960 menyita perhatian setiap golongan masyarakat Indonesia, bukan hanya karena undangundang tersebut merupakan suatu peraturan yang baru, tetapi lebih-lebih karena undang-

\footnotetext{
${ }^{8}$ Peter Mahmud Marzuki, Penelitian Hukum, Kencana, Jakarta: 2005, hlm 35.

${ }^{9}$ Johny Ibrahim, Teori dan Metodologi Penelitian Hukum Normatif, Bayumedia, Malang: 2007, hlm 248.

${ }^{10}$ Gunawan Wiradi, Seluk Beluk Masalah Agraria: Reforma Agraria dan Penelitian Agraria, Sajogyo Institute dan Sekolah Tinggi Pertanahan Nasional, Yogyakarta, 2009, hlm. 56.

${ }^{11}$ Ady Kusnadi Dkk, Penelitian Tentang Efektifitas Peraturan Perundang-Undangan Larangan Tanah Absentee, Badan Pembinaan Hukum Nasional Departemen Kehakiman dan Hak Asasi Manusia Republik Indonesia, Jakarta: 2001, hlm 1.
} 
undang tersebut benar-benar memuat hal-hal yang merupakan revolusioner dan drastis terhadap stelsel hukum agraria yang berlaku hingga sekarang. ${ }^{12}$

Pemberlakuan UUPA tidak hanya sebagai pengganti UU Agraria 1980 tetapi juga untuk perombakan total dari pewarisan sistem hukum Agraria kolonial Belanda. Terdapat 3 prinsip yang diusung oleh UUPA yaitu: ${ }^{13}$

a. mengubah sistem agraria kolonial ke sistem agraria nasional sesuai dengan kepentingan negara dan rakyat Indonesia, dan khususnya petani Indonesia;

b. untuk mengakhiri sistem dualisme dan meletakkan dasar-dasar untuk mengadakan kesatuan dan kesederhanaan dalam hukum pertanahan terutama didasarkan atas hukum adat; dan

c. memberikan kepastian hukum mengenai hak atas tanah untuk rakyat seluruhnya.

Secara normatif pemberlakuan UUPA telah menghapuskan produk-produk hukum kolonial Belanda sebagaimana yang tercantum dalam diktum "Memutuskan", seperti : (1) Agrarische Wet (Stbl. 1870-55) sebagai yang termuat dalam Pasal 51 Wet op de Staatsinrichting van Nederlands Indie (Stbl. 1925-447); (2) seluruh Domeinverklaring dari pemerintah kolonial baik yang umum maupun yang khusus; (3) peraturan mengenai Agrarische Eigendom yang diatur dalam Koninklijk Besluit tanggal 16 April 1872 No. 29 (Stbl. 1872-117) dan peraturan pelaksananya; (4) Buku ke-II Kitab Undang-Undang Hukum Perdata sepanjang yang mengenai bumi, air serta kekayaan alam yang terkandung didalamnya kecuali ketentuan-ketentuan mengenai hypotheek.

UUPA dalam kehidupan berbangsa dan bernegara sangat penting dirasakan karena hubungan antara bangsa Indonesia dengan tanah merupakan hal yang sangat mendasar dan asasi. Jika hubungan ini tidak diatur oleh peraturan yang bersifat populis maka akan lahir kemiskinan, ketidakadilan, serta sengketa dan konflik bagi sebagian rakyat Indonesia yang dapat bersifat berkepanjangan dan struktural. Kemiskinan terutama disebabkan oleh lemahnya akses masyarakat untuk mendapatkan sumber-sumber ekonomi, termasuk yang utama adalah akses terhadap pemilikan $\operatorname{tanah}^{14}$.

UUPA menyadari akan berharganya sebuah tanah dari segi ekonomisnya, sehingga UUPA memberikan batasan-batasan pemilikan suatu tanah. Hal ini tercermin pada Pasal 7 UUPA, bahwasanya pemilikan dan penguasaan tanah yang melampaui batas tidak diperkenankan karena dapat merugikan kepentingan umum. Negara mengakui hak tiaptiap individu dalam pemilikan dan penguasaan tanah namun pemilikan dan penguasaan

\footnotetext{
${ }^{12}$ Sudargo Gautama dan Ellyda T. Soetijarto, Tafsiran Undang-Undang Pokok Agraria (1960) dan PeraturanPeraturan Pelaksanannya (1996), Cetakan ke-sepuluh, Citra Aditya Bakti, Bandung: 1997, hlm 3.

13 Ahmad Nashih Luthfi, Dkk, Kronik Agraria Indonesia Memperluas Imajinasi Lintas Zaman, Sektor dan Aktor, diterbitkan atas kerjasama STPN Press, Sajogyo Institute dan Institute Sejarah Sosial Indonesia, Yogyakarta: 2010, hlm 14.

${ }^{14}$ Muhammad Ilham Arisaputra, Reforma Agraria Di Indonesia, Sinar Grafika, Jakarta: 2015, hlm 316.
} 
tanah tersebut tidak boleh sampai mengakibatkan terganggunya kepentingan yang lebih besar yakni kepentingan umum.

Pengaturan batasan-batasan pemilikan dan penguasaan tanah tersebut selanjutnya diatur dalam Pasal 17 Ayat (1) UUPA yakni pengaturan luas maksimal dan/atau minimum tanah yang boleh untuk dipunyai dengan sesuatu hak dalam Pasal $16^{15}$ oleh satu keluarga atau badan hukum. Dalam rangka untuk mensejahrakan rakyat, UUPA membawa semangat pembaruan dalam bidang keagrariaan yang dalam tataran implementasi lebih dikenal sebagai Landreform.

Istilah Landreform dalam arti restrukturisasi penguasaan dan pemanfaatan sumberddaya agraria sudah dikenal cukup lama, meski dalam bentuk dan sifat yang berbeda-beda ${ }^{16}$ tergantung pada zaman dan negara tempat terjadinya Landreform tersebut.

Dengan ditetapkannya pengaturan batasan luas maksimal penguasaan dan pemilikan tanah pertanian sebagaimana yang tercantum dalam Pasal 17 Ayat (1) UUPA maka pemilikan dan penguasaan tanah pertanian yang melebihi batas tidak diperkenankan lagi. Oleh karena itu, berdasarkan Undang-Undang Nomor 56 Prp Tahun 1960 Tentang Penetapan Luas Lahan Pertanian menetapkan luasan tanah maksimal yang dapat dimiliki oleh seseorang.

Pada dasarnya penetapan batas maksimal penguasaan dan pemilikan tanah pertanian ditetapkan untuk mencapai suatu tujuan, yakni agar pemilikan tanah pertanian selanjutnya akan lebih merata dan adil. Selain untuk memenuhi syarat keadilan maka akan berakibat pula pada bertambahnya produksi, karena para penggarap yang telah menjadi pemilik tanah akan lebih giat di dalam mengerjakan usaha pertaniannya. ${ }^{17}$

Pemilikan tanah pertanian secara absentee baru dapat dikatakan demikian apabila tanah pertaninan tersebut terletak di luar kecamatan tempat tinggal pemiliknya. Hal ini tidak berlaku bagi pemilik yang tinggal di kecamatan yang bersebelahan dengan kecamatan letak tanahnya. Pemilikan tanah pertanian secara absentee tidak sejalan dengan asas tanah pertanian dikerjakan secara aktif oleh pemiliknya.

Selain letak tanah berada diluar kecamatan tempat tinggal pemiliknya, ada beberapa penyebab yang mendasari terjadinya pemilikan tanah pertanian secara absentee, antara lain: ${ }^{18}$

\footnotetext{
${ }^{15}$ Hak yang dimaksud dalam Pasal 16 UUPA antara lain (a) hak milik, (b) hak guna usaha, (c) hak guna bangunan, (d) hak pakai, (e) hak sewa, (f) hak membuka tanah, (g) hak memungut hasil hutan, dan (h) hak-hak lain yang tidak termasuk dalam hak-hak tersebut di atas yang akan ditetapkan dengan undang-undang, serta hakhak yang sifatnya sementara sebagai yang disebutkan dalam Pasal 53.

${ }^{16}$ Gunawan Wiradi, Reforma Agraria: Perjalanan yang belum berakhir, Insist Pers, KPA dan Pustaka Pelajar, Yogyakarta: 2000, hlm 63.

17 P. Sunaryo Basuki, Dkk., Analisis dan Evaluasi Hukum Tentang Batas Pemilikan Tanah Di Daerah Perkotaan, Badan Pembinaan Hukum Nasional Departemen Kehakiman RI: 1999, hlm. 29.

${ }^{18}$ Urip Santoso, Hukum Agraria kajian komprehensif, Kencana, Jakarta: 2013.,hlm. 219.
} 

a. pemilik tanah pertanian meninggalkan kecamatan letak tanahnya;
b. seseorang yang menerima warisan tanah pertanian yang letaknya berada di kecamatan lain; dan
c. seseorang yang membeli tanah pertanian yang tempat tinggalnya terletak diluar kecamatan yang berbatasan di mana tanah pertanian tersebut terletak.

\section{Pengaturan Pemilikan Tanah Pertanian Secara Absentee Menurut PP No. 224 Tahun 1961}

Larangan pemilikan tanah pertanian secara absentee adalah salah satu bentuk kebijakan yang terdapat dalam program Landreform. Dengan demikian maka dapat pula dikatakan bahwa gagalnya Landreform karena larangan pemilikan tanah absentee yang didasarkan pada batas maksimal tanah pertanian tidak dapat dilaksanakan dengan baik. ${ }^{19}$

Larangan pemilikan tanah pertanian secara absentee adalah suatu bentuk perwujudan dari asas "tanah pertanian wajib diusahakan sendiri secara aktif". Hal ini secara filosofi sejalan dengan pandangan masyarakat petani terhadap tanah pertanian. Petani memandangan tanah pertanian adalah sumber kehidupan, hal ini mendorong para petani untuk terus mengolah tanah pertaniannya untuk meningkatkan taraf kehidupannya.

Hal tersebut sesuai dengan Pasal 3 Ayat (1) PP No. 224 tahun 1961 yang menyebutkan bahwa "Pemilik tanah yang bertempat tinggal diluar kecamatan tempat letak tanahnya, dalam jangka waktu 6 bulan wajib mengalihkan hak atas tanahnya kepada orang lain di kecamatan tempat letak tanah itu atau pindah ke kecamatan letak tanah tersebut.

Berkaitan dengan political will dari suatu rezim pemerintah, political will dipandang sangat berkontribusi dalam pelaksanaan Landreform karena setiap pemerintahan memiliki prioritas kerja yang ingin diselesaikan dalam masa jabatannya. Landreform dapat sukses dan terlaksana dengan baik apabila landreform menjadi agenda utama dalam masa pemerintahan. Political will dari masa pemerintahan sukarno pada waktu itu harus mempertahankan keseimbangan kekuatan antara kelompok politik yang bertikai, karena itu political will untuk melaksanakan program Landreform pada saat itu tidak mudah untuk dipaksakan pelaksanaannya. ${ }^{20}$

Penetapan larangan pemilikan tanah pertanian secara absentee dalam Pasal 10 (1) UUPA secara jelas diperuntukkan semua warga negara Indonesia. Namun dalam tataran yang lebih teknis, ada pengecualian terhadap pemilikan tanah pertanian secara absentee tersebut. Sulitnya menerapkan kebijakan larangan pemilikan tanah absentee salah satu sebabnya adalah adanya legalitas pengecualian pemilikan tanah pertanian secara absentee. Secara khusus beberapa pihak yang dikecualikan dari ketentuan pemilikan tanah pertanian secara absentee adalah:

19 Ady Kusnadi Dkk, Penelitian Tentang Efektifitas Peraturan Perundang-Undangan Larangan Tanah Absentee.., Op. Cit., hlm. 52.

${ }^{20}$ ibid 
a. Pegawai Negeri Sipil dan Tentara Nasional Indonesia, yang dipersamakan dengan itu, yaitu pensiunan janda pegawai negeri sipil yang tidak kawin lagi dengan bukan pagawai negeri sipil, isteri dan anak-anak pegawai negeri sipil dan Tentara Nasional Indonesia yang masih menjadi tanggungan.

b. Mereka yang sedang menjalankan tugas negara atau menunaikan kewajiban agama.

c. Mereka yang memiliki alasan khusus lainnya yang dapat diterima oleh Kepala Badan Pertanahan Nasional Republik Indonesia.

Sejalan dengan itu maka diadakan ketentuan pula dalam penjelasan umum PP No. 4 Tahun 1977, bahwa seorang pegawai negeri dalam waktu 2 (dua) tahun menjelang pensiun diperbolehkan membeli tanah pertanian secara guntai. Tetapi luas tanah yang dimilikinya secara guntai itu tidak boleh melebihi 2/5 (dua perlima) dari luas maksimum untuk Daerah Tingkat II yang bersangkutan. Pemilikan tanah itu boleh diteruskannya setelah pensiun dan sekiranya kemudian ia berpindah tempat tinggal ke Kecamatan letak tanah tersebut, maka pemilikan itu dengan sendirinya dapat ditambah hingga seluas batas maksimum. $^{21}$

Pengecualian pemilikan tanah pertanian ini tentu jika ditinjau berdasarkan asas yang terkandung dalam Pasal 10 Ayat (1) UUPA, maka dapat dikatakan bertentangan. Selain bertentangan dengan asas tanah pertanian harus dikerjakan atau diusahakan secara aktif oleh pemiliknya sendiri, pengecualian pemilikan tanah pertanian secara absentee tersebut juga bertentangan dengan asas persamaan bagi setiap waarga negara Indonesia yang terdapat pada Pasal 9 Ayat (2) UUPA.

Bagi Pegawai Negeri Sipil (PNS), Polisi, Tentara, dan yang dipersamakan dengan mereka, termasuk istri dan anak-anaknya yang masih di bawah tanggugan, dikecualikan dari larangan absentee tersebut, namun terbatas pada pemilikan tanah pertanian sampai seluas 2/5 luas maksimal pemilikan tanah pertanian yang diperbolehkan bagi Kabupaten/Kota di mana tanahnya terletak. Di dalam perkecualian itu termasuk pula pemilikan oleh isteri dan anak-anaknya yang masih menjadi tanggungannya.

Achmad Shodiki, ${ }^{22}$ menyatakan bahwa larangan pemilikaan tanah pertanian secara absentee seperti yang ditentukan dalam Pasal 10 UUPA belum tampak hasilnya, malah sebaliknya para pemilik modal (uang) lebih banyak menanamkan uangnya dalam bentuk tanah yang menurut perhitungannya tidak mungkin harga tanah akan menurun, karena persediaan tanah tetap atau malah semakin berkurang, sedangkan permintaan akan tanah semakin bertambah.

${ }^{21}$ Penjelasan umum PP No. 4 Tahun 1977

${ }^{22}$ Achmad Shodiki, Pembaruan Hukum Pertanahan Nasional Reforma Agraria, Jakarta: 2001, hlm 84. 
Selain itu ketentuan larangan pemilikan tanah pertanian secara absentee sering dimanipulasi dengan pemberian kuasa mutlak. Orang kota sebagai pembeli tanah tidak dapat memenuhi syarat untuk mengkonversikan jual beli, sehingga memberikan kuasa mutlak kepada seseorang, dengan demikian larangan orang luar kecamatan untuk memiliki tanah dapat dilangar. Selain itu juga pemilikan tanah pertanian secara absentee dapat disimpangi dengan Pasal pengecualian yaitu Pasal 3 Ayat (4) PP No. 224 tahun 1961 pengecualian tersebut diperuntukan bagi para pegawai negeri, Polisi, Tentara, serta terdapat tambahan dalam PP No. 4 tahun 1977 yakni janda dan janda pensiunan pegawai negeri, Polisi dan Tentara.

Secara hukum sulit dinyatakan bahwa suatu bidang tanah dikategorikan absentee, hal ini pula yang menyebabkan hasil sensus tanah pertanian tidak dapat mengungkapkan bahwa secara faktual tanah yang bersangkutan adalah tanah absentee. Fenomena pemilikan tanah absentee merupakan fenomena yang biasa terlihat atau terdengan khususnya di pulau Jawa. Jual beli tanah pertanian yang mengakibatkan pemilikan secara absentee tidak dicatat di Kantor Badan Pertanahan Nasional secara formal. Jual beli tanah yang bersangkutan hanya sebatas di buat akta jual elinya di hadapan Pejabat Pembuat Akta Tanah (PPAT), dan tidak di tindaklanjuti dengan proses pendaftarannya di kantor BPN setempat. Akibatnya tanah tersebut tidak tercatat pada kantor BPN. Selain itu tidak adanya sanksi kepada pihak penerima tanah yang tidak mendaftarkan tanahnya ke BPN, sehingga pola jual beli tanah pertanian tersebut mengakibatkan administrasi pertanahan menjadi tidak tertib.

Upaya penanggulangan untuk mengatasi permasalahan pemilikan tanah pertanian secara absentee perlu dilaksanakan kembali dan dilakukan dengan cara yang lebih masif. Terdapat dua hal yang perlu dilaksanakan, pertama, peninjauan relevansi peraturan yang berkenaan dengan tanah absentee masih relevan atau perlu ditinjau kembali. Perlu dipertimbangkan kembali hal-hal yang berkaitan dengan jarak antara domisili dan letak tanah, mengingat kemajuan di bidang komunikasi dan transportasi. Kedua, perlu di kaji ulang tentang pengecualian yang diberikan kepada PNS, Polisi dan Tentara tentang pengecualian pemilikan tanah pertanian secara absentee.

\section{Penyelesaian Konflik Pengaturan Pemilikan Tanah Pertanian Secara Absentee Berdasarkan Asas Preferensi}

Konflik hukum yang terjadi antara Pasal 3 Ayat (4) Peraturan Pemerintah Nomor 224 Tahun 1960 Tentang Pelaksanaan Pembagian Tanah dan Pemberian Ganti Kerugian dengan Pasal 10 Ayat (1) Undang-Undang Nomor 5 Tahun 1960 Tentang Peraturan Dasar Pokok-Pokok Agraria telah membawa pada adanya konflik hukum. Dalam menyelesaikan konflik hukum tersebut maka berlakulah asas-asas penyelesaian konflik (asas preferensi), yaitu: ${ }^{23}$

${ }^{23}$ M. Bakri, Pengantar Hukum Indonesia, Op. Cit,. hal 277-321 
a. Lex superior derogat legi inferior, yaitu apabila terjadi konflik hukum antara peraturan perundang-undangan yang lebih tinggi tingkatannya dengan peraturan perundang-undangan yang lebih rendah tingkatannya, maka peraturan perundang-undangan yang lebih rendah tingkatannya dikesampingkan/tidak diberlakukan.

b. Lex specialis derogat legi generalis, yaitu apabila terjadi konflik hukum antara peraturan perundang-undangan yang bersifat khusus (special) dengan peraturan perundang-undangan yang bersifat umum (general) maka peraturan perundang-undangan yang bersifat umum dikesampingkan/tidak diberlakukan.

c. Lex posteriori derogat legi priori, yaitu apabila terjadi konflik hukum antara peraturan perundang-undangan yang baru dengan peraturan perundang-undangan yang lama, maka peraturan perundang-undangan yang lama dikesampingkan/tidak diberlakukan.

Dalam menyelesaikan konflik perundang-undangan antara UUPA dengan PP No. 224 tahun 1961 tersebut, dapat diselesaikan dengan menggunakan asas lex superior derogat legi inferior. Asas ini digunakan ketika terjadi konflik peraturan perundangundangan yang memiliki hierarki berbeda. Adapun hierarki peraturan perundangundangan di Indonesia dapat dilihat dalam Pasal 7 Ayat (1) Undang-Undang Nomor 12 Tahun 2011 Tentang Pembentukan Peraturan Perundang-Undangan, yakni:

1. Undang-Undang Dasar Negara Republik Indonesia Tahun 1945;

2. Ketetapan Majelis Permusyawaratan Rakyat;

3. Undang-Undang/Peraturan Pemerintah Pengganti Undang-Undang;

4. Peraturan Pemerintah;

5. Peraturan Presiden;

6. Peraturan Daerah Provinsi; dan

7. Peraturan Daerah Kabupaten/Kota.

Dengan demikian, menurut asas lex superiori derogat legi inferiori PP No. 224 Tahun 1961 khususnya Pasal 3 Ayat (4) dinyatakan dikesampingkan/tidak berlaku karena bertentangan dengan Pasal 10 Ayat (1) UUPA. Hal in diperkuat lagi dari hasil analisis pada bab sebelumnya, Pasal 3 Ayat (4) PP No. 224 Tahun 1961 juga bertentangan dengan asas-asas agraria seperti asas persamaan bagi seiap Warga Negara Indonesia dan asas tanah pertanian harus dikerjakan sendiri secara aktif oleh pemiliknya sendiri dan mencegah cara-cara pemerasan.

\section{E. PENUTUP}

Konflik peraturan yang terjadi tentang pemilikan tanah pertanian secara absentee di atas menimbulkan tumpang tindihnya peraturan yang ada. Sehungga membuat pelaksanaan dalam lapangan sering sekali dimanfaatkan oleh oknum-oknum yang ingin mengambil keuntungan sebesar-besarnya. Sinkronisasi peraturan yang berkaitan dengan pertanahan dibutuhkan 
dengan segera supaya ada kesamaan hukum yang adil yang dapat dirasakan oleh seluruh rakyat Indonesia. Dalam upaya menyelesaikan konflik hukum tersebut dapat dilakukan dengan mengembalikan aturan-aturan tersebut kepada asas yang berlaku dalam lingkup hukum agraria, asas yang digunakan, yaitu: 1. Asas persamaan bagi setiap Warga Negara Indonesia, 2. Asas tanah pertanian harus dikerjakan sendiri secara aktif oleh pemiliknya sendiri dan mencegah cara-cara pemerasan.

Peneliti memberikan saran bahwa harus ada upaya preventif dan represif dalam menyelesaikan konflik pertanahan. Secara konkrit yaitu:

1. Melakukan pengkajian ulang secara bertahap dan menyeluruh terhadap berbagai peraturan perundang-undangan yang berkaitan dengan agraria dalam rangka sinkronisasi peraturan perundang-undangan.

2. Menyelesaikan keseluruhan konflik-konflik agraria yang selama ini belum terselesaikan serta mengantisipasi potensi konflik di masa mendatang guna menjamin terlaksananya penegakkan hukum.

3. Melaksanakan penataan kembali penguasaan, pemilikan, penggunaan dan pemanfaatan tanah yang berkeadilan.

4. Melakukan pendataan pertanahan kembali melalui inventarisasi dan registrasi penguasaan, pemilikan, penggunaan dan pemanfaatan tanah secara komprehensif dan sistematis.

5. Melakukan sinkronisasi peraturan perundang-undangan dengan menggunakan asas preferensi, yakni : 1. Lex superior derogat legi inferior, 2. Lex specialis derogat legi generalis, 3. Lex posteriori derogat legi priori.

\section{DAFTAR PUSTAKA}

\section{Buku:}

Achmad Shodiki, Pembaruan Hukum Pertanahan Nasional Reforma Agraria, Jakarta: 2001.

Ahmad Nashih Luthfi, Dkk, Kronik Agraria Indonesia Memperluas Imajinasi Lintas Zaman,

Sektor dan Aktor, diterbitkan atas kerjasama STPN Press, Sajogyo Institute dan Institute Sejarah Sosial Indonesia, Yogyakarta: 2010.

Ady Kusnadi Dkk, Penelitian Tentang Efektifitas Peraturan Perundang-Undangan Larangan

Tanah Absentee, Badan Pembinaan Hukum Nasional Departemen Kehakiman dan Hak Asasi Manusia Republik Indonesia, Jakarta: 2001.

Benhard Limbong, Politik Pertanahan, Margaretha Pustaka, Jakarta: 2014.

Gunawan Wiradi, Reforma Agraria: Perjalanan yang belum berakhir, Insist Pers, KPA dan Pustaka Pelajar, Yogyakarta: 2000.

Sajogyo Institute dan Sekolah Tinggi Pertanahan Nasional, Yogyakarta: 2009. 
Ida Nurlinda, Prinsip-prinsip Pembaruan Agraria: Perspektif Hukum, Rajawali Pers, Jakarta: 2009.

I Gede Pantja Astawa dan Inna Junaenah, Indeks Otonomi Daerah: Tawaran Titik Temu Negara Hukum dan Pembangunan di Aras Lokal, dalam Susi Dwi Harijati (Ed), Negara Hukum yang berkeadilan, kumpulan pemikiran dalam rangka purnabakti Prof. Dr. Bagir Manan, S.H., M.Cl., PSKN FH UNPAD, Bandung: 2011.

Isrok dan Dhia Al Uyun, Ilmu Negara (Berjalan dalam Dunia Abstrak), UB Press, Malang: 2010 .

Johny Ibrahim, Teori dan Metodologi Penelitian Hukum Normatif, Bayumedia, Malang: 2007.

M. Bakri, Pengantar Hukum Indonesia, Sistem Hukum Indonesia Pada Era Reeformasi, UB Press, Malang: 2011.

Muhammad Ilham Arisaputra, Reforma Agraria Di Indonesia, Sinar Grafika, Jakarta: 2015.

Peter Mahmud Marzuki, Penelitian Hukum, Kencana, Jakarta: 2005.

P. Sunaryo Basuki, Dkk., Analisis dan Evaluasi Hukum Tentang Batas Pemilikan Tanah Di Daerah Perkotaan, Badan Pembinaan Hukum Nasional Departemen Kehakiman RI: 1999.

Satjipto Rahardjo, Ilmu Hukum, Cetakan Keenam, Citra Aditya Bakti, Bandung: 2006.

Soehino, Ilmu Negara, edisi ke-3 cetakan pertama, Liberty, Yogyakarta: 1998.

Sudargo Gautama dan Ellyda T. Soetijarto, Tafsiran Undang-Undang Pokok Agraria (1960) dan Peraturan-Peraturan Pelaksanannya (1996), Cetakan ke-sepuluh, Citra Aditya Bakti, Bandung: 1997.

Supriadi, Hukum Agraria, Sinar Grafika, Jakarta: 2007.

\section{Sumber Lainnya}

Catatan Akhir Tahun 2015, Membenahi Masalah Agraria : Prioritas Kerja Jokowi-JK Pada 2015, Konsosrsium Pembaruan Agraria, Jakarta, 2015

2016, Liberalisasi Agraria Diperhebat, Reforma Agraria Dibelokkan, Konsorsium Pembaruan Agraria, Jakarta, 2016

, 2017, Reformasi Agrarai di Bawah Bayangan Investasi: Gaung Besar di Pinggiran Jalan, Konsorsium Pembaruan Agraria, Jakarta, 2017 